\title{
Phosphoinositide 3-kinase/Akt and nuclear factor $\kappa B$ pathways are involved in tumor necrosis factor-related apoptosis-inducing ligand resistance in human gastric cancer cells
}

\author{
JING LIU，XIUJUAN QU，LING XU，YE ZHANG，JINGLEI QU，KEZUO HOU and YUNPENG LIU \\ Department of Medical Oncology, The First Hospital of China Medical University, Shenyang 110001, P.R. China
}

Received January 18, 2010; Accepted March 1, 2010

DOI: $10.3892 / \mathrm{mmr} 00000286$

\begin{abstract}
Human gastric cancer cells are generally believed to be less sensitive to tumor necrosis factor-related apoptosisinducing ligand (TRAIL)-induced apoptosis, but the events responsible for this resistance are as yet unclear. In this study, we investigated the role of the phosphoinositide 3-kinase $(\mathrm{PI} 3 \mathrm{~K}) / \mathrm{Akt}$, nuclear factor $\kappa \mathrm{B}(\mathrm{NF}-\mathrm{\kappa B})$ and extracellular signal-regulated kinase (ERK) signaling pathways in the TRAIL resistance of gastric cancer cells. TRAIL failed to induce observable apoptosis in the three cell lines. Further investigation revealed that TRAIL engagement led to the activation of PI3K/Akt as well as of NF- $\mathrm{KB}$. The inhibition of PI3K/Akt by a specific inhibitor facilitated TRAIL-induced apoptosis. Blockage of TRAIL-induced NF- $\mathrm{KB}$ activation by transient transfection with a phosphorylation-defective mutant I $\kappa$ also enhanced the sensitivity of cells towards TRAIL. Meanwhile, ERKs were highly activated in the resting cells and were not further activated by TRAIL treatment. However, the inhibition of ERK activity by PD98059 also enhanced the apoptosis-inducing ability of TRAIL. Our data demonstrated that the activation of PI3K/Akt and NF- $\mathrm{KB}$ by TRAIL is responsible for resistance to TRAIL in human gastric cancer cells. Blockage of survival signals significantly enhances the apoptosis induced by TRAIL.
\end{abstract}

\section{Introduction}

Gastric cancer is one of the most common malignancies worldwide, particularly in eastern Asian countries such as China, Japan and Korea (1). Although combinational chemotherapy has brought about some improvements, the prognosis

Correspondence to: Dr Yunpeng Liu, Department of Medical Oncology, The First Hospital of China Medical University, Shenyang 110001, P.R. China

E-mail: cmuliuyunpeng@yahoo.cn

Key words: tumor necrosis factor-related apoptosis-inducing ligand, phosphoinositide 3-kinases/Akt, nuclear factor $\kappa \mathrm{B}$, extracellular signal-regulated kinases, gastric cancer, apoptosis in cases of advanced disease remains very poor (2). A truly effective regimen for the treatment of advanced gastric cancer has not yet been established.

Recently, a biological agent in the form of a monoclonal antibody exhibited significant therapeutic benefits in the treatment of breast, lung and colon cancer (3-5). These results confirm that biological therapy is a promising method for cancer treatment. Tumor necrosis factor (TNF)-related apoptosis-inducing ligand (TRAIL) is a member of the TNF superfamily, which induces apoptosis through the engagement of death receptors. Unlike other members of the TNF family, TRAIL preferentially induces apoptosis in a variety of tumor cells, whereas it has only slight toxicity towards most normal cells and induces a mild inflammatory response $(6,7)$. This selective toxicity for cancer cells and induction of low-level inflammation make TRAIL a potential tumor-specific cancer therapy. Clinical trials using agonistic monoclonal antibodies specific for TRAIL receptors (DR4 or DR5) have achieved promising results in patients with advanced solid malignancies $(8,9)$.

Despite the powerful activity of TRAIL towards most types of cancer cells, some tumors display intrinsic or acquired resistance to TRAIL-induced apoptosis $(10,11)$. Previous studies by our group and others have shown that gastric cancer cells are less sensitive towards TRAIL-induced apoptosis (12-14). A thorough understanding of the mechanisms involved in TRAIL resistance is very important to overcome the resistance and facilitate the clinical use of TRAIL. TRAIL resistance can occur at different steps in the signaling cascade, and may involve several mechanisms. Some signaling pathways that are critical for cell proliferation and survival, such as the phosphoinositide 3-kinase (PI3K)/Akt, nuclear factor $\kappa \mathrm{B}$ (NF- $\kappa \mathrm{B})$ and extracellular signal-regulated kinase (ERK) pathways, are also involved in TRAIL-mediated apoptosis. It has been reported that highly active PI3K/Akt signaling is associated with TRAIL resistance, and blockage of the PI3K/Akt pathway reverses the resistance to TRAIL in certain primary resistant tumor cells $(15,16)$. However, the NF- $\mathrm{KB}$ and ERK pathways play diverse roles in TRAIL-induced apoptosis. NF- $\mathrm{KB}$ activation is usually thought to have an anti-apoptotic effect. It maintains TRAIL resistance in human pancreatic cancer cells, but does not modulate the sensitivity of renal carcinoma cells to TRAIL $(17,18)$. In melanoma cells, the activation of ERK has been reported to protect against TRAIL-induced apoptosis; 
however, in lung cancer cells the activation of ERK is required for PG490-mediated sensitization to TRAIL $(19,20)$. These controversial results suggest that the role of each signaling pathway in TRAIL-induced apoptosis in different tumors is in need of further individual study.

To further investigate the associated molecules involved in TRAIL resistance, in the present study we investigated the effects of TRAIL on the activities of the PI3K/Akt, NF- $\kappa$ B and ERK pathways, as well as the role they play in TRAILmediated apoptosis in three human gastric cancer cell lines. Our data demonstrated that these survival signals interrupt TRAIL-induced apoptosis. Individual inhibition of any of these signals may partially reverse resistance to TRAILinduced apoptosis.

\section{Materials and methods}

Cell cultures. The human gastric cancer cells MGC803, BGC823 and SGC7901 were obtained from the Type Culture Collection of the Chinese Academy of Sciences (Shanghai, China). The cells were cultured in RPMI-1640 medium (Gibco) containing 10\% heat-inactivated fetal bovine serum (FBS), penicillin $(100 \mathrm{U} / \mathrm{ml})$ and streptomycin $(100 \mathrm{mg} / \mathrm{ml})$ at $37^{\circ} \mathrm{C}$ under an atmosphere of $95 \%$ air and $5 \% \mathrm{CO}_{2}$. The cells were routinely subcultured every 2-3 days, and were all from the logarithmic phase of growth.

Reagents and antibodies. Recombinant human TRAIL/Apo2L was from Cytolab/Peprotech Asia (USA). LY294002, PD98059 and DiOC6 were purchased from Sigma-Aldrich (USA). Anti-phospho-Akt (Ser-473), anti-Akt, anti-phospho-ERK, anti-ERK, anti-I $\kappa \mathrm{B} \alpha$ and anti-tubulin antibodies were purchased from Santa Cruz Biotechnology (USA).

Cell viability assay. Cell viability was measured using a 3-(4,5-dimethylthiazol-2-yl)-2,5-diphenyltetrazolium bromide (MTT) assay. The cells were seeded at $5 \times 10^{4}$ cells/well in 96-well plates, incubated overnight and then exposed to the indicated concentrations of TRAIL for the indicated times. Thereafter, $20 \mu \mathrm{l}$ of MTT solution $(5 \mathrm{mg} / \mathrm{ml}$ ) was added to each well, and the cells were incubated for another $4 \mathrm{~h}$ at $37^{\circ} \mathrm{C}$. After removal of the culture medium, the cells were lysed in $200 \mu \mathrm{l}$ of dimethylsulfoxide (DMSO), and the optical density (OD) was measured at $570 \mathrm{~nm}$ with a microplate reader (Model 550; Bio-Rad Laboratories, USA). The following formula was used: cell viability $=(O D$ of the experimental sample/OD of the control group) x $100 \%$.

Analysis of apoptosis. Cells were seeded at $3 \times 10^{5}$ cells/well in 6-well plates, incubated overnight and then exposed to the indicated concentrations of TRAIL for the indicated times. The cells were then collected and washed twice with phosphate-buffered saline (PBS). After being fixed with ice-cold $70 \%$ ethanol for $12 \mathrm{~h}$, the samples were washed twice with PBS and then incubated with $20 \mu \mathrm{g} / \mathrm{ml}$ RNase A at $37^{\circ} \mathrm{C}$ and $10 \mu \mathrm{g} / \mathrm{ml}$ propidium iodide for $30 \mathrm{~min}$ in the dark. Finally, the samples were evaluated by flow cytometry, and the data were analyzed by WinMDI software.
Western blotting. Cells were washed twice with ice-cold PBS and solubilized in $1 \%$ Triton lysis buffer [ $1 \%$ Triton $\mathrm{X}-100$, $50 \mathrm{mM}$ Tris-Cl (pH 7.4), $150 \mathrm{mM} \mathrm{NaCl}, 10 \mathrm{mM}$ EDTA, $100 \mathrm{mM} \mathrm{NaF}, 1 \mathrm{mM} \mathrm{Na} \mathrm{VO}_{4}, 1 \mathrm{mM}$ PMSF and $2 \mu \mathrm{g} / \mathrm{ml}$ aprotinin] on ice, then quantified using the Lowry method. Cell lysate proteins $(50 \mu \mathrm{g})$ were separated by sodium dodecyl sulfate-polyacrylamide gel electrophoresis and electrophoretically transferred to nitrocellulose membranes (Immoblin-P; Millipore, USA). The membranes were blocked with 5\% skim milk in TBST buffer [10 mM Tris (pH 7.4), $150 \mathrm{mM} \mathrm{NaCl}$ and $0.1 \%$ Tween-20] at room temperature for $1 \mathrm{~h}$ and incubated overnight at $4^{\circ} \mathrm{C}$ with the indicated primary antibodies. After the membranes were washed with TBST buffer, they were reacted with the appropriate horseradish peroxidase-conjugated secondary antibodies for $30 \mathrm{~min}$ at room temperature. After extensive washing with TBST buffer, the proteins were visualized with enhanced chemiluminescence reagent (SuperSignal Western Pico Chemiluminescent Substrate; Pierce, Rockford, IL, USA).

Transient transfection. Transient transfection was performed using Lipofectamine 2000 reagent (Invitrogen, USA), according to the manufacturer's instructions. Briefly, the cells were seeded in 6-well plates at a density of $5 \times 10^{5}$ cells/well and incubated for $24 \mathrm{~h}$. Before transfection, Lipofectamine $(6 \mu \mathrm{l})$ was diluted dropwise into OPTI-MEM and incubated at room temperature for $5 \mathrm{~min}$. Then, $2 \mu \mathrm{g}$ of empty vector or hemagglutinin-tagged phosphorylation-defective mutant I $\mathrm{B}$ expression constructs were added to the diluted Lipofectamine and incubated for another $20 \mathrm{~min}$ before being dropped into the medium. After $48 \mathrm{~h}$ of transfection, the cells were subcultured for further use.

Statistical analysis. The experiments were repeated at least three times. Data are expressed as the means \pm SD. Differences in the results for two groups were evaluated by the Student's t-test. $\mathrm{P}<0.05$ was considered to be statistically significant.

\section{Results}

Human gastric cancer cells are resistant to TRAIL-induced apoptosis. Three human gastric cancer cell lines, MGC803, BGC823 and SGC7901, were exposed to $1-1,000 \mathrm{ng} / \mathrm{ml}$ TRAIL for 24 or $48 \mathrm{~h}$. As shown in Fig. 1A, the inhibitory effects of TRAIL on the proliferation of the three cell lines reached the plate phase at $100 \mathrm{ng} / \mathrm{ml}$. Compared with the untreated control, TRAIL at $100 \mathrm{ng} / \mathrm{ml}$ reduced cell viability to $70.67 \pm 5.13 \%$ in MGC803 cells, to $93.67 \pm 3.21 \%$ in BGC823 cells, and to $99.67 \pm 2.52 \%$ in SGC7901 cells, respectively. Even if the dose of TRAIL was increased to $1,000 \mathrm{ng} / \mathrm{ml}$ or the exposure prolonged to $48 \mathrm{~h}$, there was no further increase in cytotoxicity (Fig. 1B). Flow cytometric analysis showed that $100 \mathrm{ng} / \mathrm{ml}$ TRAIL induced $<8 \%$ apoptosis in the three cell lines (Fig. 1C), whereas the same concentration of TRAIL induced $>90 \%$ apoptosis in TRAIL-sensitive Jurkat T cells (data not shown). These data indicate that gastric cancer cells are resistant to TRAIL-triggered apoptosis.

The PI3K/Akt signaling pathway is activated by TRAIL and prevents cells from undergoing apoptosis. To determine the 
A

$24 \mathrm{~h}$

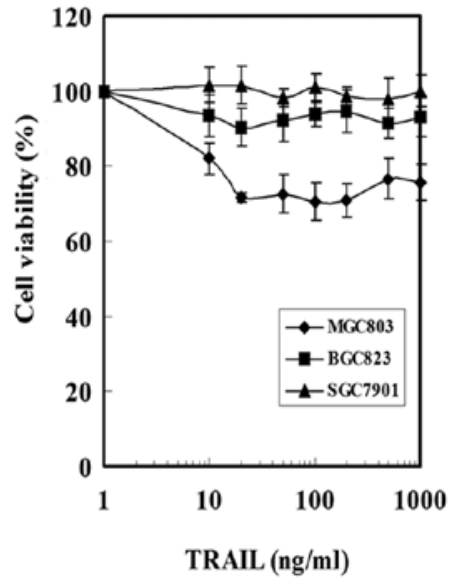

B

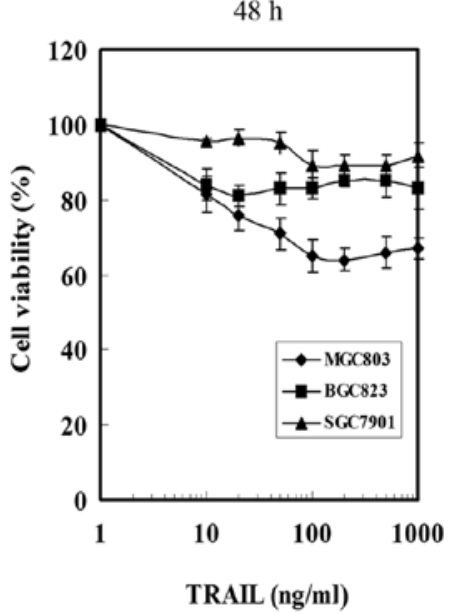

C

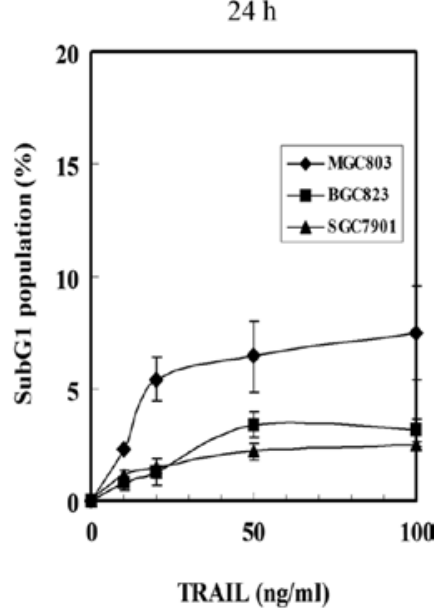

Figure 1. Effect of TRAIL on the cell viability of human gastric cancer cells. Human gastric cancer cells MGC803, BGC823 and SGC7901 were exposed to 1-1,000 ng/ml TRAIL for 24 (A) or $48 \mathrm{~h}$ (B), and cell viability was measured by the MTT assay. Data are the means \pm SD of three independent experiments performed in triplicate. (C) The cells were exposed to $0-100 \mathrm{ng} / \mathrm{ml}$ TRAIL for $24 \mathrm{~h}$, and the apoptosis was analyzed by flow cytometry following staining with propidium iodide. Data are the means \pm SD of three independent experiments.

A

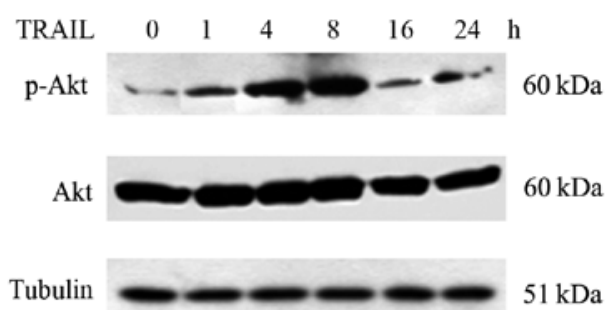

B LY294002 - - + +

TRAIL - +-+

p-Akt $=60 \mathrm{kDa}$

Akt

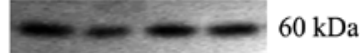

Tubulin $51 \mathrm{kDa}$
C

CTRL LY294002 TRAIL

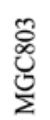
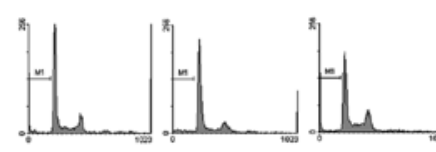

Ð్ర
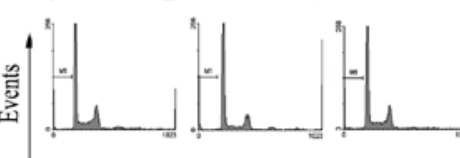

তু
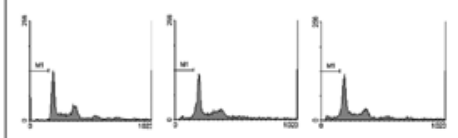

FI.2-A
LY294002+

\section{TRAIL}

D

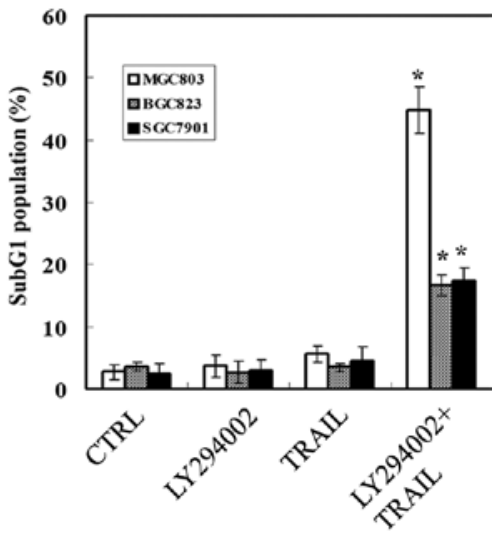

Figure 2. The PI3K/Akt signaling pathway is activated by TRAIL and prevents cells from undergoing apoptosis. (A) SGC7901 cells were exposed to 100 $\mathrm{ng} / \mathrm{ml}$ TRAIL for the indicated time, and the level of phospho(p)-Akt was detected by Western blotting. (B) SGC7901 cells were pre-treated with $50 \mu \mathrm{M}$ LY294002 for $1 \mathrm{~h}$, then exposed to $100 \mathrm{ng} / \mathrm{ml}$ TRAIL for an additional $8 \mathrm{~h}$, and the level of phospho-Akt was determined by Western blotting. The total Akt and tubulin were used as the internal loading control. Blots are representative of three independent experiments. (C and D) MGC803, BGC823 and SGC7901 cells were pre-treated with $50 \mu \mathrm{M} \mathrm{LY} 294002$ for $1 \mathrm{~h}$, then exposed to $100 \mathrm{ng} / \mathrm{ml}$ TRAIL for an additional $24 \mathrm{~h}$, and the apoptosis was detected by flow cytrometry following propidium iodide staining. Histograms are representative of three independent experiments, and the columns are the means \pm SD of three independent experiments. ${ }^{*} \mathrm{P}<0.05$ vs. cells treated with TRAIL alone.

role of the PI3K/Akt signaling pathway in TRAIL-induced apoptosis, we investigated Akt activation in the most resistant SGC7901 cells after treatment with $100 \mathrm{ng} / \mathrm{ml}$ TRAIL for 1-24 h. Upon TRAIL treatment, the phosphorylation of Akt increased at $1 \mathrm{~h}$, reached a peak at $8 \mathrm{~h}$, declined, and thereafter remained at the basal level (Fig. 2A). Pre-treatment with LY294002, the specific inhibitor of PI3K, followed by exposure to TRAIL reduced the phosphorylation of Akt at $8 \mathrm{~h}$ (Fig. 2B). We next investigated whether the inhibition of Akt activity affects TRAIL-induced apoptosis. As shown in Fig. 2C and D, TRAIL or LY294002 alone induced $<5 \%$ apoptosis in the three cell lines, whereas pre-treatment 
A

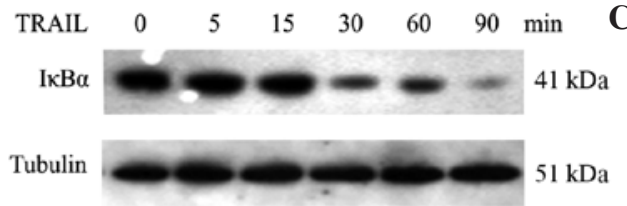

B
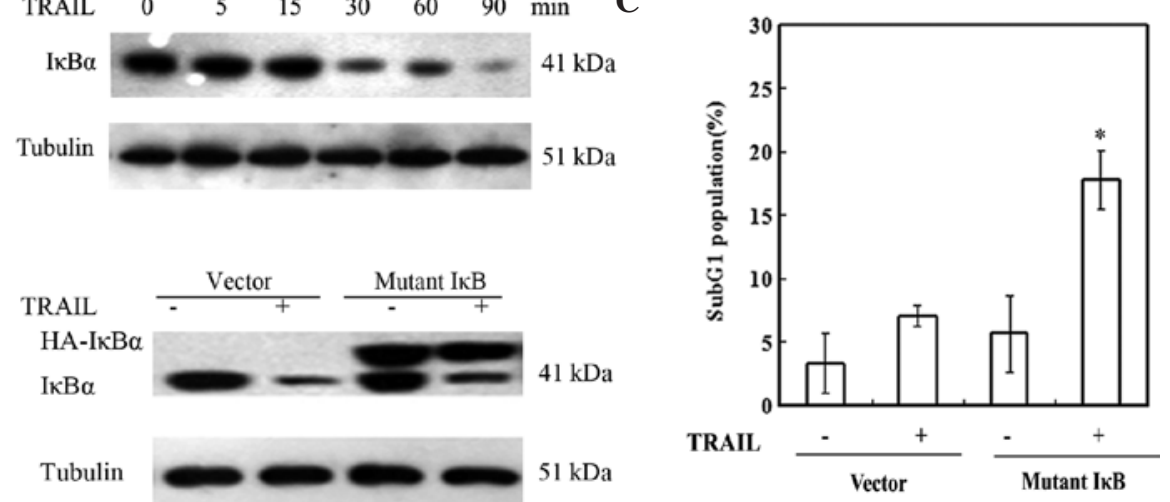

Figure 3. TRAIL-triggered rapid activation of NF- $\mathrm{kB}$ contributes to the resistance towards TRAIL. (A) SGC7901 cells were exposed to $100 \mathrm{ng} / \mathrm{ml}$ TRAIL for the indicated time, and the level of IкB was detected by Western blotting. (B) SGC7901 cells were transiently transfected with an empty vector or a cDNA

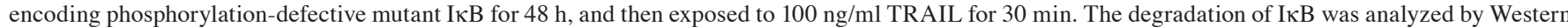
blotting. Tubulin was used as the internal loading control. Blots are representative of three independent experiments. (C) After transient transfection for $48 \mathrm{~h}$, the SGC7901 cells were treated with $100 \mathrm{ng} / \mathrm{ml}$ TRAIL for $24 \mathrm{~h}$, and the apoptosis was analyzed by flow cytometry following propidium iodide staining. Columns are the means \pm SD of three independent experiments. $* \mathrm{P}<0.05$ vs. cells transfected with the empty vector and treated with TRAIL alone.

A

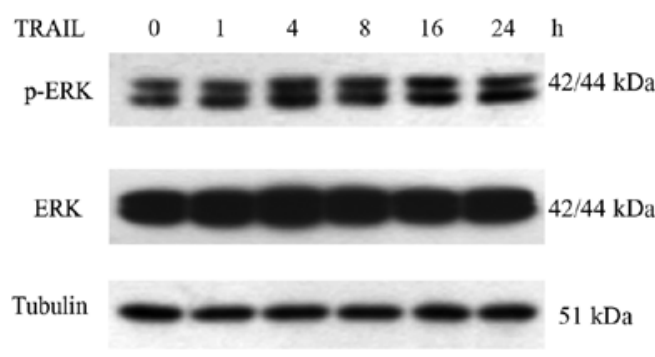

B

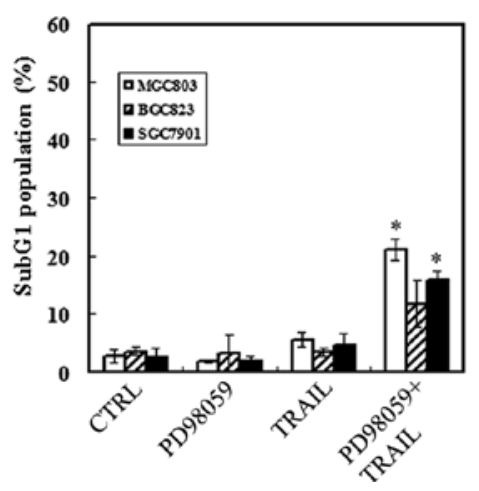

Figure 4. Inhibition of the ERK pathway also increases the sensitivity of cells to TRAIL-induced apoptosis. (A) SGC7901 cells were exposed to $100 \mathrm{ng} /$ $\mathrm{ml}$ TRAIL for the indicated time, and the level of phospho(p)-ERK was detected by Western blotting using specific antibodies. (B) MGC803, BGC823 and SGC7901 cells were pre-treated with $20 \mu \mathrm{M}$ PD98059 for $1 \mathrm{~h}$, then exposed to $100 \mathrm{ng} / \mathrm{ml}$ TRAIL for an additional $24 \mathrm{~h}$. The apoptosis was analyzed by flow cytometry following propidium iodide staining. Columns are the means \pm SD of three independent experiments. " $\mathrm{P}<0.05$ vs. cells treated with TRAIL alone.

with LY294002 followed by TRAIL exposure significantly increased the apoptotic population to $44.73 \pm 3.75 \%$ in MGC803 cells, to $17.38 \pm 2.14 \%$ in SGC7901 cells, and to $16.62 \pm 1.68 \%$ in BGC823 cells, respectively $(\mathrm{P}<0.05)$. These data indicate that the TRAIL-induced activation of the PI3K/Akt pathway is responsible for the resistance of cells towards TRAIL-induced apoptosis.

TRAIL-triggered rapid activation of $N F-\kappa B$ contributes to resistance towards TRAIL. We next investigated the role of $\mathrm{NF}-\kappa \mathrm{B}$ signaling in TRAIL-induced apoptosis. In SGC7901 cells, TRAIL triggered rapid activation of NF- $\mathrm{B}$, as evidenced by the clear degradation of I $\kappa \mathrm{B}$ at as early as $30 \mathrm{~min}$, maintained up to $90 \mathrm{~min}$ after TRAIL treatment (Fig. 3A). SGC7901 cells were then transiently transfected with either an empty vector or a cDNA encoding a phosphorylation-defective mutant $\mathrm{I} \kappa \mathrm{B}$. The mutant $\mathrm{I} \kappa \mathrm{B}$ protein did not undergo degradation at 30 min upon TRAIL treatment, which indicated that the $\mathrm{NF}-\kappa \mathrm{B}$ signaling pathway was inactivated in the cells overexpressing mutant IкB (Fig. 3B). Analysis of apoptosis indicated that, in the cells transfected with the empty vector, TRAIL induced only $7.09 \pm 0.84 \%$ apoptosis. By contrast, in the cells overexpressing mutant I $\mathrm{B}$, TRAILtriggered apoptosis was increased to $17.80 \pm 2.34 \%(\mathrm{P}<0.05)$ (Fig. 3C). These data indicate that the rapid activation of NF- $\kappa \mathrm{B}$ by TRAIL protects gastric cancer cells from TRAILinduced apoptosis, and the inactivation of the NF- $\kappa \mathrm{B}$ pathway enhances the apoptosis-inducing ability of TRAIL.

Inhibition of the ERK pathway increases the sensitivity of cells to TRAIL. Unlike the PI $3 \mathrm{~K} / \mathrm{Akt}$ and $\mathrm{NF}-\kappa \mathrm{B}$ signaling pathways, ERK was already highly activated in the resting SGC7901 cells, and the incubation of the cells with TRAIL for 1-24 h did not further enhance the activity of ERK (Fig. 4A). However, pre-treatment with PD98059, a specific inhibitor of ERK signaling, also enhanced the TRAIL-induced apoptosis. As shown in Fig. 4B, TRAIL or PD98059 alone induced $<5 \%$ apoptosis in the three cell lines, whereas in the presence of PD98059, the apoptosis induced by TRAIL was increased to $21.18 \pm 1.75 \%$ in MGC803 cells, to $15.7 \pm 1.9 \%$ in SGC7901 
cells, and to $11.86 \pm 4.00 \%$ in BGC 823 cells, respectively $(\mathrm{P}<0.05)$. These data indicate that although TRAIL has little effect on ERK activity, the high activity of ERKs at a basal level also interrupts TRAIL-triggered apoptosis.

\section{Discussion}

The resistance of gastric cancer cells towards TRAIL-induced apoptosis limits the use of TRAIL as a potent antitumor agent. Several attempts to conquer TRAIL resistance in gastric cancer cells have been made in the last couple of years. Usually, TRAIL induces obvious apoptosis in the most sensitive cells at a concentration under $100 \mathrm{ng} / \mathrm{ml}$. In the present study, the inhibitory effect of TRAIL reached the plate phase at $100 \mathrm{ng} / \mathrm{ml}$. Even when the dose of TRAIL was increased to $1,000 \mathrm{ng} / \mathrm{ml}$ or the exposure time prolonged to $48 \mathrm{~h}$, cytotoxity was not further enhanced. This is consistent with results from other trials involving TRAIL-resistant tumor cells (21), and indicates that the cytotoxity of TRAIL on resistant cells cannot be enhanced simply by increasing the dose of TRAIL or by prolonging the exposure time. Other avenues must therefore be explored to overcome the resistance.

Recent studies have revealed that the down-regulation of anti-apoptotic molecules by other reagents enhances the apoptosis-inducing ability of TRAIL in gastric cancer cells (22-24). However, these studies overlooked a possibility which has been found in other tumor cells: that TRAIL activates certain survival signals so as to interrupt the apoptosis cascade (10). In the present study, we focused on the effect of TRAIL on PI3K/Akt, NF- $\kappa \mathrm{B}$ and ERK, the three major signaling pathways involved in cell proliferation and survival. PI3K/Akt is a major signaling pathway that regulates cell survival, growth and apoptosis. It can be induced by a wide range of stimuli and often acts as an anti-apoptotic signal (25). Previous studies have shown that a high level of PI3K/Akt activity in cancer cells is responsible for TRAIL resistance (26-28). Nevertheless, little is known regarding whether TRAIL is capable of triggering further Akt activation in TRAIL-resistant tumor cells. Recently, Chen et al reported that TRAIL activated Akt in hepatocellular carcinoma cells and prevented cell death (29). Here, we provide evidence that TRAIL also activates PI3K/Akt in gastric cancer cells, and the inhibition of Akt activity significantly enhances the sensitivity of cells to TRAIL-induced apoptosis. These results indicate that TRAIL activates the PI3K/ Akt signaling pathway, depressesing the apoptosis-inducing effect and leading to TRAIL resistance.

It has been reported that the engagement of TRAIL with its receptors activates $\mathrm{NF}-\kappa \mathrm{B}$, which in turn initiates the transcription of several anti-apoptotic genes and protects cells from TRAIL-induced apoptosis (30). The inhibition of $\mathrm{NF}-\kappa \mathrm{B}$ activity increases the sensitivity of a variety of tumor cells towards TRAIL $(17,31,32)$. However, in some cases, $\mathrm{NF}-\kappa \mathrm{B}$ inactivation fails to enhance the apoptosis triggered by TRAIL $(18,33,34)$. Ishiguro et al reported that an ingredient of ginger, 6-gingerol, reduced the viability of gastric cancer cells by inhibiting NF- $\kappa \mathrm{B}$ activation (22). However, as a herbal component 6-gingerol also has biological effects other than the blocking NF- $\kappa \mathrm{B}$ activation, and the inhibition of $\mathrm{NF}-\kappa \mathrm{B}$ activity may be indirect and secondary to the other events.
In the present study, the $\mathrm{NF}-\kappa \mathrm{B}$ signal was inactivated by the overexpression of a mutant I $\mathrm{B}$ cDNA in SGC7901 cells. The inactivation of $\mathrm{NF}-\kappa \mathrm{B}$ was found to significantly enhance apoptosis in response to TRAIL. This is the first evidence that the specific inhibition of NF- $\mathrm{NB}$ activity enhances TRAILmediated apoptosis in gastric cancer cells, which indicates that, like the PI3K/Akt signal, NF- $\mathrm{KB}$ acts as an apoptotic inhibitor in gastric cancer cells.

ERKs are members of the MAP kinases, a superfamily of proteins that transmits signaling cascades from extracellular stimuli into cells. Usually, the activation of ERKs in response to death stimuli is believed to have an anti-apoptotic effect, based on the evidence of TRAIL-induced rapid ERK activation in certain tumor cell lines, and the inhibition of this activation sensitizes TRAIL-resistant tumor cells to TRAIL $(19,35)$. On the other hand, ERK activation has been reported to have pro-apoptotic effects in TRAIL-mediated apoptosis in lung and prostate cancer cells $(20,36)$. However, the role of ERK on TRAIL-mediated apoptosis in gastric cancer cells has not as yet been studied. Data from our study demonstrated that ERK was over-activated in the resting gastric cancer cells. Although TRAIL did not further activate ERK, the inhibition of ERK activity with a specific inhibitor significantly enhanced the apoptosis-inducing effect of TRAIL. This indicates that ERK signaling also protects gastric cancer cells from TRAIL-induced apoptosis.

Taken together, our data demonstrate that, in human gastric cancer cells, PI3K/Akt and NF- $\mathrm{KB}$ are activated by TRAIL and serve as survival signals to protect cells from TRAILinduced apoptosis. A highly activated ERK signaling pathway is also involved in TRAIL resistance. Combined treatment of TRAIL with several inhibitors or with an inhibitor which has an effect on multiple signaling pathways may be a promising tool for the treatment of gastric cancer.

\section{Acknowledgements}

We thank Dr Ashwell (National Institutes of Health, USA) for providing the phosphorylation-defective mutant I $\mathrm{I} B$ expressing plasmid. This work was supported by the National Natural Science Foundation of China (grant no. 30770993), the Liaoning Province Natural Science Foundation (grant no. 20072100) and the China Postdoctoral Science Foundation (grant no. 20070411081)

\section{References}

1. Kamangar F, Dores GM and Anderson WF: Patterns of cancer incidence, mortality and prevalence across five continents: defining priorities to reduce cancer disparities in different geographic regions of the world. J Clin Oncol 24: 2137-2150, 2006.

2. Liakakos T and Roukos DH: More controversy than ever - challenges and promises towards personalized treatment of gastric cancer. Ann Surg Oncol 15: 956-960, 2008.

3. Tedesco KL, Thor AD, Johnson DH, et al: Docetaxel combined with trastuzumab is an active regimen in HER-2 3+ overexpressing and fluorescent in situ hybridization-positive metastatic breast cancer: a multi-institutional phase II trial. J Clin Oncol 22: 1071-1077, 2004. 
4. Butts CA, Bodkin D, Middleman EL, et al: Randomized phase II study of gemcitabine plus cisplatin or carboplatin [corrected], with or without cetuximab, as first-line therapy for patients with advanced or metastatic non-small cell lung cancer. J Clin Oncol 25: 5777-5784, 2007.

5. Tabernero J, van Cutsem E, Díaz-Rubio E, et al: Phase II trial of cetuximab in combination with fluorouracil, leucovorin and oxaliplatin in the first-line treatment of metastatic colorectal cancer. J Clin Oncol 25: 5225-5232, 2007.

6. Ashkenazi A: Targeting death and decoy receptors of the tumournecrosis factor superfamily. Nat Rev Cancer 2: 420-430, 2002.

7. Ashkenazi A, Pai RC, Fong S, et al: Safety and antitumor activity of recombinant soluble Apo2 ligand. J Clin Invest 104: 155-162, 1999.

8. Greco FA, Bonomi P, Crawford J, et al: Phase 2 study of mapatumumab, a fully human agonistic monoclonal antibody which targets and activates the TRAIL receptor- 1 , in patients with advanced non-small cell lung cancer. Lung Cancer 1: 82-90, 2008.

9. Plummer R, Attard G, Pacey S, et al: Phase 1 and pharmacokinetic study of lexatumumab in patients with advanced cancers. Clin Cancer Res 13: 6187-6194, 2007.

10. Zhang L and Fang B: Mechanisms of resistance to TRAIL-induced apoptosis in cancer. Cancer Gene Therapy 12: 228-237, 2005.

11. Van Geelen CM, de Vries EG and de Jong S: Lessons from TRAIL-resistance mechanisms in colorectal cancer cells: paving the road to patient-tailored therapy. Drug Resist Updat 7: 345-358, 2004

12. Shimoyama S, Mochizuki Y, Kusada O, et al: Supra-additive antitumor activity of $5 \mathrm{FU}$ with tumor necrosis factor-related apoptosis-inducing ligand on gastric and colon cancers in vitro. Int J Oncol 21: 643-648, 2002.

13. $\mathrm{Xu} \mathrm{L,} \mathrm{Qu} \mathrm{X,} \mathrm{Zhang} \mathrm{Y,} \mathrm{et} \mathrm{al:} \mathrm{Oxaliplatin} \mathrm{enhances} \mathrm{TRAIL-}$ induced apoptosis in gastric cancer cells by CBL-regulated death receptor redistribution in lipid rafts. FEBS Lett 583: 943-948, 2009.

14. Hu JK, Yang K, Li CM, et al: The expression of TRAIL and its receptors in gastric cancer and the apoptotic effect of rh-TRAIL on SGC7901 cells. Oncol Rep 21: 681-688, 2009

15. Tazzari PL, Tabellini G, Ricci F, et al: Synergistic proapoptotic activity of recombinant TRAIL plus the Akt inhibitor Perifosine in acute myelogenous leukemia cells. Cancer Res 68: 9394-9403, 2008.

16. Rychahou PG, Murillo CA and Evers BM: Targeted RNA interference of PI3K pathway components sensitizes colon cancer cells to TNF-related apoptosis-inducing ligand (TRAIL). Surgery 138: 391-397, 2005.

17. Khanbolooki S, Nawrocki ST, Arumugam T, et al: Nuclear factor-kappaB maintains TRAIL resistance in human pancreatic cancer cells. Mol Cancer Ther 5: 2251-2260, 2006.

18. Pawlowski JE, Nesterov A, Scheinman RI, et al: NF-kappaB does not modulate sensitivity of renal carcinoma cells to TNF alpha-related apoptosis-inducing ligand (TRAIL). Anticancer Res 20: 4243-4255, 2000

19. Zhang XD, Borrow JM, Zhang XY, et al: Activation of ERK1/2 protects melanoma cells from TRAIL-induced apoptosis by inhibiting Smac/DIABLO release from mitochondria. Oncogene 22: 2869-2881, 2003 .
20. Frese S, Pirnia F, Miescher D, et al: PG490-mediated sensitization of lung cancer cells to Apo2L/TRAIL-induced apoptosis requires activation of ERK2. Oncogene 22: 5427-5435, 2003.

21. Wang P, Zhang J, Bellail A, et al: Inhibition of RIP and c-FLIP enhances TRAIL-induced apoptosis in pancreatic cancer cells. Cell Signal 19: 2237-2246, 2007.

22. Ishiguro K, Ando T, Maeda O, et al: Ginger ingredients reduce viability of gastric cancer cells via distinct mechanisms. Biochem Biophys Res Commun 362: 218-223, 2007.

23. Jin CY, Park C, Cheong J, et al: Genistein sensitizes TRAILresistant human gastric adenocarcinoma AGS cells through activation of caspase-3. Cancer Lett 257: 56-64, 2007.

24. Chaudhari AA, Seol JW, Kang SJ, et al: Mitochondrial transmembrane potential and reactive oxygen species generation regulate the enhanced effect of CCCP on TRAIL-induced SNU-638 cell apoptosis. J Vet Med Sci 70: 537-542, 2008.

25. Kim D and Chung J: Akt: versatile mediator of cell survival and beyond. J Biochem Mol Biol 35: 106-115, 2002

26. Oka N, Tanimoto S, Taue R, et al: Role of phosphatidylinositol-3 kinase/Akt pathway in bladder cancer cell apoptosis induced by tumor necrosis factor-related apoptosis-inducing ligand. Cancer Sci 97: 1093-1098, 2006.

27. Shankar E, Sivaprasad U and Basu A: Protein kinase C epsilon confers resistance of MCF-7 cells to TRAIL by Akt-dependent activation of $\mathrm{Hdm} 2$ and downregulation of $\mathrm{p} 53$. Oncogene 27: 3957-3966, 2008.

28. Nam SY, Jung GA, Hur GC, et al: Upregulation of FLIP(S) by Akt, a possible inhibition mechanism of TRAIL-induced apoptosis in human gastric cancers. Cancer Sci 94: 1066-1073, 2003.

29. Chen KF, Yeh PY, Hsu C, et al: Bortezomib overcomes TRAIL resistance in hepatocellular carcinoma cells in part through the inhibition of PI3K/Akt pathway. J Biol Chem 284: 11121-11133, 2009.

30. Burstein E and Duckett CS: Dying for NF-kappaB? Control of cell death by transcriptional regulation of the apoptotic machinery. Curr Opin Cell Biol 15: 732-737, 2003.

31. Zhang X, Huang X and Olumi AF: Repression of NF-kappaB and activation of AP-1 enhance apoptosis in prostate cancer cells. Int J Cancer 124: 1980-1989, 2009.

32. Ammann JU, Haag C, Kasperczyk H, et al: Sensitization of neuroblastoma cells for TRAIL-induced apoptosis by NF-kappaB inhibition. Int J Cancer 124: 1301-1311, 2009.

33. $\mathrm{Hu} \mathrm{WH}$, Johnson $\mathrm{H}$ and Shu HB: Tumor necrosis factor related apoptosis-inducing ligand receptors signal NF-kappaB and JNK activation and apoptosis through distinct pathways. J Biol Chem 274: 30603-30610, 1999.

34. Kim Y, Suh N, Sporn M, et al: An inducible pathway for degradation of FLIP protein sensitizes tumor cells to TRAIL-induced apoptosis. J Biol Chem 277: 22320-22329, 2002.

35. Lunghi P, Giuliani N, Mazzera L, et al: Targeting MEK/MAPK signal transduction module potentiates ATO-induced apoptosis in multiple myeloma cells through multiple signaling pathways. Blood 112: 2450-2462, 2008

36. Kim YH, Lee DH, Jeong $\mathrm{JH}$, et al: Quercetin augments TRAIL-induced apoptotic death: involvement of the ERK signal transduction pathway. Biochem Pharmacol 75: 1946-1958, 2008. 